\title{
The Concept of Moderation within the Context of Leadership in Malaysia
}

\author{
Wan Kamal Mujani \\ Azyati Azhani Mohd Mazuki \\ Department of Arabic Studies and Islamic Civilization, Faculty of Islamic Studies, \\ The National University of Malaysia
}

\begin{abstract}
Leadership is an important aspect in a country's development and shaping of its society. The advancement of a nation is dependent on its leadership. With that in mind, this article aims to shed light on the concept of moderation from the perspective of the leadership of Malaysia's Prime Ministers. The main focus of this study is the concept of moderation utilised by Dato' Seri Mohd Najib Tun Razak's leadership through aspects such as politics, economy and social. The methodology used in this study is document analysis and historical research, which enabled us to obtain complete data. The results of this study show that the concept of moderation does indeed exist in his leadership, in his quest to bring the nation on par with other developed countries.
\end{abstract}

Keywords: moderation, leadership, Malaysia, Prime Ministers

\section{Introduction}

The ultimate mandate of a leader is to provide an environment conducive for his people in a fair and just manner, preventing any untoward circumstances so that the nation and its people will remain in a state of well-being. Malaysia is a multi-racial country with over 200 ethnicities; with Malays, Chinese and Indians being the majority of the country's population (Abdul Rahman, 2010). With that said, each leader has his own way of propelling the country towards achievements on the political, economic, social, education and safety front; and this indirectly harmonizes racial relations through the concept of moderation. This is down to the fact that the concept of moderation is responsible for providing balance in all aspects of human life and can be implemented in activities of daily living for the betterment of the nation's development.

Good leadership is one which is thorough and intelligent in carrying out responsibilities especially with regards to racial sensitivities. Otherwise, disunity will occur and tarnish the nation's reputation. Leadership and management responsibilities at the individual, family, society and national level are all borne by the leaders. The success and advancement of a nation relies heavily on its leadership style (Abd Ghani, 2011). Successful leadership has the ability to influence an individual's behaviour; with the purpose of giving out orders, providing guidance, and maintaining the strength and unity of an organization with solid competency.

\section{Definition of Leadership}

Leadership is a vital aspect in the development of a nation and is given great value, both by the Islamic and Western communities alike. Muslim scholars agree that leadership is one of the pillars of religion. A task is deemed as incomplete without the presence of leadership (Hamzah, 2010). So much so, that the Prophet Muhammad PBUH has urged that a leader be appointed even in a group of few persons, as evident in his Hadith: When three persons set out on a journey, they should appoint one of them as their leader. Apart from that, Islam also lays out a leadership hierarchy and mandate as follows:

Surely! Every one of you is a guardian and is responsible for his charges: The Imam (ruler) of the people is a guardian and is responsible for his subjects; a man is the guardian of his family (household) and is responsible for his subjects; a woman is the guardian of her husband's home and of his children and is responsible for them; and the slave of a man is a guardian of his master's property and is responsible for it. Surely, every one of you is a guardian and responsible for his charges. 
In Islam, leadership is a mandate given to an individual to manage a group or an organization (Haddara \& Enanny, 2009). A leader neglecting that responsibility will ultimately have a negative impact towards the governing of his nation. With that being said, leadership is not something special that should be fought over because it is in its essence, a mandate. The Prophet Muhammad PBUH once reminded Abu Dhar al-Ghifari (whom had asked for a position of leadership), which translates to:

Abu Dhar, thou art weak and authority is a trust. And on the Day of Judgment it is a cause of humiliation and repentance except for one who fulfils its obligations and (properly) discharges the duties attendant thereon (Muhamat, 2010).

Leadership is not something to take lightly because it involves an enormous responsibility put by the people on an individual's shoulder to govern the country towards becoming a developed Muslim nation. Islam outlines 5 major responsibilities in leadership which are: upholding Islamic principles, protecting the Karamat al-Insan (human dignity), prospering the earth, upholding justice and Islah (reform) which is essentially the improvement of society via appropriate means.

According to Kamus Dewan (the official Malaysian authorized dictionary for the Malay language), the meaning behind leadership is the ability to lead, where the term 'lead' is synonymous with 'guide', 'direct', and 'propel'. Meanwhile, the term 'leading' is synonymous with 'guiding', 'captaining', 'heading' and 'propelling' (Baharom, 2007).

On the other hand, the Western world defines leadership as the process by which an individual influences a group of people to achieve a common objective (Northouse, 2011). There are a number of scholars whom shed light on the meaning of leadership, including Charles Handy. He defines leadership as having vision and mission, and awards points for the tasks accomplished (Karimi, 2007). Furthermore, quoting Joanne Ciulla (2004), leadership is not actually a person or a position, but rather a complex moral relationship amongst humans based on shared trust, commitment, emotions and vision.

Leadership can be further defined as follows:

The effort of influencing an individual or a group of individuals to complete a task in order to achieve a certain objective.

An individual's behaviour when he is instructing a group activity towards a common aim.

The art of forming relationships between individuals with multiple groups of people which directs them towards a planned objective.

An effective and influential leadership style (al-Qiyadah al-Mu'assirah) is shown through its leader's actions. Its effect and influence is not prominent through debates and discussions, but rather through the behaviour and attitude of the leader themselves. The end result is an accomplished endeavour which leads to productivity that is worthwhile.

\section{The Concept of Moderation in Each of the Nation's Leaders' Approach}

The advancement of a nation is dependent on the leadership style of its head of state. Only the best policies and agendas are handpicked by the leaders to allow the country to continue prospering without conflict. The best approach is utilized to ensure that the citizens' rights are protected, in accordance with evolving circumstances. Such is the approach taken by the first Prime Minister of Malaysia, Tunku Abdul Rahman Putera Al-Haj, to realize the dream of turning Malaysia into a developed nation that is able to keep up with the times. The affectionate nickname 'Father of Independence' is more than relevant considering the undertaking that he spearheaded which earned Malaysia's freedom as an independent and sovereign nation. The talks which he participated in spared any bloodshed. Truce was achieved with the British, and Malaysia gained its independence on 31 st August 1957. As the Prime Minister, his hope for the people in preserving of the nation's independence is captivated as follows:

All people must feel that there is room for them in our country and that we can all live in peace with one another, provided of course that we respect one another's rights, and provided, too, that we realize we owe duties to one another for the good and well-being, the progress and happiness of our country, Malaysia.

That speech given by him shows how much he valued peace and harmony. He urged the Malaysian people to always work together and help each other despite contrasting backgrounds. Furthermore, he emphasized tolerance and respect to encourage harmony within a multi-ethnic community (Abdul Rahman, 2010). Racial relations became the core of all his future undertakings where the nation's growth and development were concerned. 
After achieving independence on $31^{\text {st }}$ August 1957, racial unity was stronger than ever. Needless to say, it is evident that Tunku Abdul Rahman, the nation's highest ranking leader at the time, played a key role in terms of racial unity. This is echoed by Tan Cheng Lock whom commended Tunku as being 'a leader of the people' despite his royal heritage. As the nation's leader, Tunku realized that independence could only be achieved through cooperation between all the races in Malaysia. Hence, he formed a political party known as the Alliance Party which comprised UMNO, MIC and MCA. The alliance of these 3 political parties convinced the British to end its colonization of the Malayan Union. This early racial unity initiated by Tunku became the basis for future post-independence racial relations in Malaysia. This would later on become the core of the leadership of his predecessors (Hussin, 2009).

The tenure of the second Prime Minister, Tun Abdul Razak Hussein who was in office from 1970 until 1976, brought forth many developments for the nation, especially with regards to education. ${ }^{1} \mathrm{He}$ was a leader willing to serve the people and his nation with a lifetime of servitude. This was evident in his life principle to 'serve the people and country at all times.' From those words alone we can conclude that he was a leader who always put the people first, and his decisions always took into account their interests without jeopardizing their rights.

In the years leading up to independence, a consensus arose amongst all the nation's leaders that a comprehensive national education system was necessary to fulfil the needs of the country. Thus, the National Education Policy was born through the 1956 Razak Report and was made a part of the 1957 Education Ordinance. ${ }^{2}$ Then, a committee was appointed to study the policy to ensure that it was adequate enough to nurture a united and disciplined people; so that skilled manpower would be available to enhance the nation's development. It was also a means of inculcating national unity and integration (Abdullah, 2008).

Apart from prioritizing education, Tun Abdul Razak also put great emphasis on racial relations due to the nature of the nation's demographics. To maintain harmony and peace within the country, especially after the May $13^{\text {th }} 1969$ incident, ${ }^{3}$ he took drastic action such as suspending Parliament, declaring a state of emergency and founding MAGERAN to govern the nation on a temporary basis. He also introduced policies which strengthened ethnic relations such as the New Economic Policy, the mandatory use of Bahasa Malaysia in the education system and the National Principles (Rukun Negara), among others. All those policies had one common goal: to protect the racial sensitivities of the citizens so that such an incident will not repeat itself.

After Tun Abdul Razak's term in office ended, he was replaced by Tun Hussein Onn. ${ }^{4}$ He was a strict but fair leader, and continued to implement Tun Abdul Razak's policies starting from 1976. He was also the brainchild of a number of important

\footnotetext{
${ }^{1}$ He was a nationalist, political leader, elite member of the Malay community and a diplomat whom embodied the Malay spirit. Throughout his 7 years governing Malaysia, many efforts were done for the prosperity of the people. Among the aspects that he emphasized include stabilizing the economy by introducing the New Economic Policy. Hence, he is referred to as 'The Father of Development' for the many changes which he brought upon the nation for the sake of its advancement. See Faridah Jaafar, 2007, Perdana Menteri dan Dasar Luar Malaysia 1957-2005 (Prime Ministers and Malaysia's Foreign Policies 1957-2005), Kuala Lumpur, Penerbit Universiti Malaya, p.55.

2 The objective of the National Education Policy is to fulfil the nation's needs and encourage the growth of culture, social, the economy and politics. See Zabri Zakaria, 2010, Peralihan Dasar Perdana Menteri (Transition of the Prime Minister's Policies), Kajang, Time Edition, p.4.

${ }^{3}$ On the ill-fated date of May 13, 1969, a tragic event took place, considered as a dark cloud over the nation's history. The racial conflict that broke out led to the loss of lives and property. It was associated with the 1969 General Election and was the peak of racial disunity in Malaysia. During that year's elections, many sensitive issues were brought up such as the national language, the special rights of the Malays and citizenship of the non-Malays. In the 1969 General Election, the Alliance Party failed to gain a two-thirds majority in the House of Representatives, while DAP and the Malaysian People's Movement Party (Parti Gerakan), whom had won 25 seats, held a demonstration in the streets of Kuala Lumpur which insulted the Malays. This offended the Malays deeply, and UMNO retaliated by holding a demonstration of their own to oppose the insulting actions of DAP and Gerakan. In those tense and emotional moments, the incident of May 13, 1969 took place; a breaking point for the years of suppressed conflict dating back even before 1969. See Abdullah Md. Zin \& Khairil Annas Jusoh, 2012, Pendekatan Wasatiyyah dalam Menghayati 1Malaysia (A Wasatiyyah Approach in Embracing 1Malaysia), Kuala Lumpur, Kasturi Jingga Sdn. Bhd., p.19; Mohd Fitri Abd Rahman \& Mohd Foad Sakdan, 2013, Konflik Politik Perkauman: Strategi dan Penyelesaian Cara Malaysia (The Conflict of Racial Politics: Malaysia's Strategy and Solution), Kuala Lumpur, Dewan Bahasa dan Pustaka, p.53.

${ }^{4}$ Tun Hussein Onn was known for his emphasis on unity. He also gave a lot of importance towards respecting the law. Starting out as a practitioner of law, he then switched to politics. As the Prime Minister, he protected the people's interests especially in combating bribery
} 
changes that helped shape the nation's development and protected the people's interests. In a speech he said, I am not necessarily an important person for the country, but what is important is what I do for the country. This clearly proves how highly he values the people and country which he serves, and he always took into consideration the input of others before finalizing a decision.

Among the many efforts undertaken by Tun Hussein Onn is instilling among the people the mentality of being thrifty with their spending and saving money. He knew that this would certainly be the backbone of the country's economy via the New Economic Policy. Production of raw material such as palm oil, rubber, timber, tin ore and petroleum increased dramatically. The Third Malaysia Plan (Rancangan Malaysia Ketiga) gave much emphasis on agriculture and industrialization, aside from using education as the propelling force for the nation's advancement. Like the Prime Ministers before him, Tun Hussein Onn also gave utmost importance to the rights of each race in Malaysia. In other words, national unity is vital for the country's future aspirations to transpire. Bearing that in mind, the Board of National Unity founded in 1974 was revamped and refocused to create a united, fair and progressive community in line with the National Principles. He also gave a lot of attention to the concept of Rukun Tetangga (literal translation: Neighbourhood Association), which he believed could close the gap between citizens of different backgrounds and religion.

He also made Bahasa Melayu the official language, a move which was said to be the stepping stone towards the formation of the nation. He believed that language could be used as a tool to unite rather than divide. Aside from implementing domestic policies, he did not neglect to set in motion many plans to strengthen international bonds. Being at the helm of leadership, he continued the Non-Aligned Policy in the context of Malaysia's Foreign Affairs; and he always emphasized the Principle of Common Peace (Prinsip Keamanan Bersama), which is essentially to respect the rights and sovereignty of a state, being non-aggressive, not meddling with the affairs of a state, achieving common benefit and common peace (Abd. Hamid, 2006).

Tun Hussein Onn's steadfast approach can be clearly seen through his efforts to ensure inter-ethnic unity, political stability and the everlasting of the nation. It is only fitting that he was given the affectionate nickname of "Father of Unity" due to his strong emphasis on the spirit of nationalism.

After Tun Hussein Onn's time in office for almost 6 years, the nation's leadership was then continued by Tun Dr. Mahathir Mohamad whom held his position for an unprecedented 22 years as the fourth Prime Minister of Malaysia. ${ }^{1}$ Under his tutelage, Malaysia progressed towards an era of being a developed nation. Tun Dr. Mahathir was known as the "Father of Modernization" because ever since the beginning of his term in office, he propelled the nation towards achieving the status of a developed nation. Many efforts were taken to bring Malaysia on par with other developed nations. In terms of economic growth, he introduced a clear paradigm shift which transformed Malaysia from an agriculture-based nation to an industrialized nation with global trading power. According to this new policy, each state was instructed to initiate industrial programs by providing sites for light and medium industries, finding external investors and upgrading the infrastructure. This environment made it possible to develop those areas and provide many jobs for the local and international workforce.

Among the many accomplishments of this innovation magnate is founding the nation's very own car manufacturer, Proton. As of today, Malaysia is capable of creating new car models via collaboration with the Japanese. The introduction of the Multimedia Super Corridor emphasized IT as an asset for the people that ensured the future-proofing of the nation. The construction of Putrajaya, the Petronas Twin Towers and others is proof of his commitment towards the development of the nation and its people. The incremental use of technology directly improved the nation's income generation capacity.

As a developed nation, Tun Mahathir Mohamad planned an agenda to transform Malaysia into a fully industrialized nation by introducing Vision 2020. ${ }^{2}$ Vision 2020 not only covers the aspect of economy but also politics, social, spiritual,

to ensure that the nation's legislature and development are accounted for. See Hamidin Abd. Hamid, 2006, Tun Hussein Onn: Bapa Perpaduan (Tun Hussein Onn: Father of Unity), Kuala Lumpur, Arkib Negara Malaysia, pp.138-139.

${ }^{1} \mathrm{He}$ became the fourth Prime Minister of Malaysia on July 18, 1981. A prominent political figure, nationalist and international leader; known for his intuitive ideas, controversy and strict principles. During his leadership, Malaysia was heralded as a rising power in international politics trying to advance with a global-based industrialized economy, as well as knowledge of science and technology. See Ramlah Adam, 2004, Pemikiran Tun Dr. Mahathir Mohamad (The Mind of Tun Dr. Mahathir Mohamad), Malacca, Institut Kajian Sejarah dan Patriotisme Graha (Graha Institute of Historical Study and Patriotism), IKSEP, p.17.

2 The nine objectives of Vision 2020 are: to create a united people; to create a people whom are free, devoted to their nation, believe in themselves and admired by others; to form a mature democratic society; to construct a society which can be modelled after in terms of 
psychology and national unity. It aims to create peace, protect racial pride and prevent oppression. Within Vision 2020, he outlined nine main objectives that have to be constantly achieved without fail.

Being tasked with spearheading a multi-ethnic society, Tun Dr. Mahathir was very adept in matters concerning unity. He was quite worried with the racial divide that was occurring where the people would only stick with their own kind and would think lowly of others from a different group. Thus, he encouraged the abolishment of these ethnic groups by organizing public events that gave a chance for the people to mingle and interact. He saw that the situation was still under control and was in good shape.

This effort to cultivate racial unity was continued by Tun Abdullah Ahmad Badawi. ${ }^{1}$ Since the beginning of his leadership, he emphasized the importance of ethnic relations and made it a national agenda with the belief that good ethnic relations would serve as a strong foundation for the nation's development. He made evaluations based on the concept of moderation. He believed that being moderate and respecting others would go a long way towards solving any problem (Anon, 2009). He called upon all parties to play their part in bringing life to the spirit of nationalism in order for all conflicts to be resolved and the development to be achieved.

Apart from focusing on the aspect of unity, he also gave emphasis on economy-related issues. The national mission under the Ninth Malaysia Plan (Rancangan Malaysia Kesembilan) shows the attention he gave towards improving the citizens' quality of life in the midst of domestic and foreign competition. In one of his speeches he said:

The institutes of Wakaf (religious endowment) and Zakat (Payment made annually under Islamic law on certain kinds of property and belongings and used for charitable and religious purposes) should work hand in hand as a vital mechanism to ensure the prosperity of Muslims, especially to release them from poverty.

Despite prioritizing Muslims, he did not neglect the rights of the other races such as the Chinese, Indians and others who dwell in this country. Fairness and justice is the core of the responsibility held by a nation's leader.

Another transformational agenda brought forth by Tun Abdullah Ahmad Badawi is "Islam Hadhari" which aims to convince the Malaysian people that Islam should be the epicenter of future undertakings to ensure the nation's success. It was also used as an approach to repair the stigma that the global community had towards Muslims post-September 11, 2001 (Pandian, 2007). The stereotype of Islam being violent and inhumane was successfully abolished through debates and talks which allowed the Western world to familiarize themselves with Islam on a deeper level. This undertaking certainly proves that he was a man of moderation in carrying out his role as the nation's leader, despite holding the post for only three years.

After Tun Abdullah Ahmad Badawi resigned in April 2009, Malaysia was then spearheaded by Dato' Seri Mohd Najib Tun Abdul Razak. He introduced the 1Malaysia Concept (Gagasan 1Malaysia). This concept is actually a continuation from his two previous predecessors, Tun Dr. Mahathir Mohamad and Tun Abdullah Ahmad Badawi, whom focused on transforming Malaysia into a developed nation through the formulas of Vision 2020. The already prevalent unity of this nation needs to be strengthened to create an environment of progressiveness, peace and security. Ensuring national security and political stability will encourage the birth of a more dynamic economy for the country. Mutual respect needs to be inculcated within the people, while negative values such as suspicion, doubt and discontentment should be eliminated; because the truth of the matter is each and every race is already given their due rights.

To realize the 1Malaysia Concept that was introduced in April 2009, he also launched another agenda: the concept of Wasatiyyah, which means balance, justice and moderation. This was done to repair the negative perception that outsiders

ethics and attitude; to create an advanced and scientific society; to create a loving society; to create a society whom are economically fair; and to create a dynamic society capable of competing with others. See Harlina Ismail, 2008, Wawasan 2020 (Vision 2020) in Yusof Ismail (ed.), Dasar- dasar Utama Kerajaan Malaysia (Major Policies of the Malaysian Government, Kuala Lumpur, A.S. Nordeen, pp.203-204. 1 Tun Abdullah Ahmad Badawi was appointed as the fifth Prime Minister of Malaysia on October 31, 2003, replacing Tun Dr. Mahathir Mohamad. His leadership lasted three years. In one of his first speeches as the Prime Minister, he said, "I am deeply humbled by this responsibility which requires me to carry out my duty with trust, honesty, efficiency and fairness. I am aware that I will be evaluated by dignitaries, by the people, and most importantly, by Allah the Almighty." See Chamil Wariya, 2004, Abdullah Ahmad Badawi: Perjalanan Politik PM ke-5 (Abdullah Ahmad Badawi: The Political Journey of the Fifth Prime Minister), Kuala Lumpur, Utusan Publications \& Distributors Sdn. Bhd., p.237. 
had about Islam, and indirectly create a mutually respectful society regardless of faith (Zakaria, 2010). Such an effort is vital in preventing division amongst the people which would allow outside parties to meddle with the country's affairs.

It is therefore evident from the efforts of the nation's top brass that they always put the people's interest first and foremost. They assume the path of a moderate approach so as to protect the sensitivities and rights of each race to avoid unwanted incidents. The concept of moderation existing throughout each Prime Minister's leadership showcases Malaysia as a nation governed with good judgment calls. In one of his speeches, the President of the United States of America heaped praise on how Malaysia is able to stay on course as a developing and progressive Muslim country while still maintaining its integrity. This serves as proof that Malaysia's leaders are actually very responsible in carrying out the people's mandate, while governing and propelling Malaysia to be on par with other developed nations. Most of the agendas and policies put in place by the Prime Ministers are for the purpose of uniting and nurturing the community to ensure a smoother path for future developments to be implemented. The political stability and economic growth has enabled Malaysia to be at the forefront of all aspects of development rather than playing catch-up behind other nations.

\section{The Concept of Moderation in the Current Malaysian Leadership}

Malaysia is a country blessed with political stability, economic growth and a harmonious socio-cultural environment. As a developing nation heading towards the status of a developed nation, Malaysia remains steadfast in its mission by strengthening diplomatic relations with foreign countries to ensure more stability for itself. Currently, Malaysia is being led by a leader who puts great emphasis on the needs and wants of the country. This leader is none other than Dato' Seri Mohd Najib Tun Abdul Razak himself.

Since being appointed as the nation's highest-ranking official, he has been focused on the major issue at hand: unity; without neglecting other aspects of the country's governance. Amongst his agendas are the 1Malaysia Concept which outlines the principle of "People First, Performance Now", the concept of "Wasatiyyah" and others. The 1Malaysia Concept was a strategic plan introduced to instigate a united Malaysian race comprising of diverse ethnicities, religion and culture. 1

Through the implementation of the 1Malaysia Concept, the people's interests will always be protected regardless of religion or faith. Positive core values and mutual respect must be evident in society to avoid suspicion and doubt, more so because each race has the benefit of receiving equal rights and opportunities. However, the status of Islam as the official religion must not be questioned. This protects Islam as the official religion of this country, while giving freedom to citizens from other religions to practice their faith freely in a peaceful environment without restrictions.

The same holds true for the concept of Wasatiyyah, where Islamic norms are not neglected and devotees of various other faiths are given a chance to see that Islam is a truly universal religion. This gives security in all aspects of life within a society, more so when other races are involved. In line with the slogan 'People First, Performance Now', the concept of Wasatiyyah will bring forth more a comprehensive and universal Islamic teaching that is well-balanced in its quest to meet the country's diverse needs; which will ultimately turn Malaysia into a developed, tolerate Muslim nation to be modelled after by others (Abdul Razak, 2010).

Dato' Seri Najib also mentioned in a speech that according to verse 134 of Surah al-Baqarah, Muslims are deemed to be a people of moderation (Ummatan Wasatan), i. e. moderate in his approach, not being overzealous or extreme in the practice of his faith, virtues and deeds concerning both this world and the hereafter. Islam teaches its devotees to be balanced in all regards, controlling oneself not to indulge too much or too little. Thus, the concept of Wasatiyyah or moderation is very much applauded and encouraged by Islam, where doing too much is considered extravagant and doing too little is considered careless. Muslims must also not be too rigid or extreme, nor can they be too free without any selfrestraint.

\footnotetext{
${ }^{1}$ The 1Malaysia Concept is based on eight core values which are: a culture of excellence, resilience, humility, acceptance, loyalty, meritocracy, education and integrity. See Ismail Ibrahim, 2013, 1Malaysia Dari Perspektif Agama: Islam dalam Perlembagaan dan Amalan Umat Islam Malaysia (1Malaysia from a Religious Perspective: Islam in the constitution and the practices of Malaysian Muslims) in Mohd Sohaimi Esa, Ismail Ali, Dayu Sensalu \& Lai Yew Meng (eds.), Gagasan 1Malaysia: Isu dan Cabaran (1Malaysia Concept: Issues and Challenges), Kota Kinabalu, Universiti Malaysia Sabah, p.1.
} 
Furthermore, the Government Transformation Program has been continually improved in a mission to create a developed society with high income by the year 2020. This program is implemented through 7 National Key Result Areas which put the people's interest first, by means of reducing crime rate, improving infrastructure in rural areas and increasing the income of the poor. As a result, the people's quality of life and standard of living has improved, the nation's economy has grown exponentially and the country's finances strengthen by the day.

Dato' Seri Najib Tun Abdul Razak also strengthened diplomatic relations with "trading partner" countries such as China, Singapore and the United States of America. Such a policy was carried out to protect the nation's political, security and economic interests, among others. It also encouraged tolerance and cooperation between Malaysia and its foreign counterparts, which led to a more structured relationship with the international community. Among the other efforts which he masterminded include, but are not limited to:

Malaysian Education Development Plan.

1Malaysia People's Aid (Bantuan Rakyat 1Malaysia).

1 Malaysia Book Voucher.

1Malaysia People's Housing Program (PR1MA).

Urban Transformation Center (UTC) and Rural Transformation Center (RTC) (Omar \& Mukhtaruddin, 2010).

Implementing short, medium and long-term strategies that were outlined for the sake of the people's prosperity is no easy task. Many challenges had to be overcome before the plans became reality. Among the challenges faced include having to deal with a small minority of the population whom were religious extremists, unwilling to accept racial diversity, intolerant leaders within certain racial groups and the difficult task of creating an atmosphere of tolerance between different racial groups under the same political party.

Despite those obstacles, Dato' Seri Mohd Najib managed to carry out his duty as the leader of the nation and found effective solutions for those problems. For example, he himself along with the President of the Philippines, Benigno Aquino III, became important witnesses during the signing of the peace treaty between the Philippines government and the Moro Islamic Liberation Front (MILF), an event held in Malacanang Palace, Manila. That treaty is the epitome of Malaysia's success as the gatekeeper during talks between the Philippines government and MILF. Even so, humanity has now entered a modern era of globalization and a world without borders. The instantaneous flow of information technology has changed the way society thinks and acts, which directly affects efforts to solidify the nation and its people. Whatever the case may be, with meticulous planning and proper execution, all challenges can be overcome, one step at a time.

The core of this formula is cooperation between all parties involved regardless of position and embracing the spirit of moderation. This mentality does not intend to create a society of mediocrity and conformity, but rather a society that is wellbalanced and fulfils its potential. Any problems or hurdles must be tackled head on with that concept in mind, for the sake of strengthening the state of the nation as well as formulating policies that have a clear direction with respect to the governance of the country in terms of politics, social and economy.

\section{Conclusion}

Each leader has their own unique leadership style when it comes to implementing policies that determine the nation's path. Even though policies are renewed and revamped with the change of each new leadership, the agenda of transforming Malaysia into a developed country by the year 2020 remains the same. Based on this study, each of those leaderships embodied the spirit of moderation and succeeded in creating a nation of peace, harmony and cooperative citizens.

Such is also the case with Dato' Seri Mohd. Najib Tun Abdul Razak's current leadership. He is also imposing the concept of moderation when executing his policies. His policies lean toward the formation of an identity and culture for the society without neglecting the nation's interests in all aspects of life. Despite heavy opposition and challenging obstacles, he utilized the concept of moderation as the gist of his approach without diminishing Islamic principles and still protecting the rights of non-Muslims. The development of the nation will remain well-balanced if it continues to be incorporated with religion and positive virtues. Religion will play a major role in preventing the nation, especially its Muslim citizens, from being easily influenced and intoxicated by the sea of development, modernization, globalization, nationalism and patriotism up to a point where it becomes extreme, extinguishes the positive core values and oversteps religious boundaries.

\section{References}


[1] Abd. Hamid, Hamidin. 2006. Tun Hussein Onn: Bapa Perpaduan (Tun Hussein Onn: Father of Unity). Kuala Lumpur: Arkib Negara Malaysia.

[2] Abd Ghani, Zulkiple. 2011. Kepimpinan Islam dan pendekatan Wasatiyyah (Islamic leadership and the Wasatiyyah approach), in Muhammad Mustaqim Mohd Zarif, Paimah Atoma \& Hariza Mohd Yusof (eds. ). Islam and Wasatiyyah. Bandar Baru Nilai: Universiti Sains Islam Malaysia.

[3] Abd Rahman, Mohd Fitri \& Sakdan, Mohd Foad. 2013. Konflik Politik Perkauman: Strategi dan Penyelesaian Cara Malaysia (The Conflict of Racial Politics: Malaysia's Strategy and Solution). Kuala Lumpur: Dewan Bahasa dan Pustaka.

[4] Abdul Aziz, Abdul Rahman. 2010. Nilai-Nilai Kesepaduan Sosial Dalam Hubungan Etnik: Analisis Ucapan Enam Perdana Menteri Malaysia (Social Cohesion Values in Ethnic Relations: An Analysis of Speeches by Six Malaysian Prime Ministers). Sintok: Universiti Utara Malaysia.

[5] Abdul Razak, Najib. 2010. via http://1malaysia. com. my/speeches/majlis-perjumpaan-yab-perdana-menteribersama-ulama-dan-umara-serta-pelancaran-logo-baru-agensi-agama-dan-persekutuan-dan-negeri/ (October 30, 2013).

[6] Abdullah, Fadzilah. 2008. Dasar Pendidikan Kebangsaan (National Education Policy) in Yusof Ismail (ed. ). Dasar-dasar Utama Kerajaan Malaysia (Major Policies of the Malaysian Government). Kuala Lumpur: Percetakan Zafar Sdn. Bhd.

[7] Adam, Ramlah. 2004. Pemikiran Tun Dr. Mahathir Mohamad (The Mind of Tun Dr. Mahathir Mohamad). Melaka: Institut Kajian Sejarah dan Patriotisme Graha (Graha Institute of Historical Study and Patriotism). IKSEP.

[8] Anon. 2009. Membawa Perubahan: Himpunan Ungkapan Bestari Tun Abdullah Ahmad Badawi (Bringing Change: A Collection of Tun Abdullah Ahmad Badawi's Words of Wisdom). Kuala Lumpur: Institut Tadbiran Awam Negara (INTAN).

[9] Baharom, Noresah. 2007. Kamus Dewan - Edisi ke-Empat (Kamus Dewan - Fourth Edition), Kuala Lumpur: Dewan Bahasa dan Pustaka.

[10] Ciulla, Joanne. 2004. Ethics, the Heart of Leadership. U. S. A: Praeger Publishers.

[11] Haddara, Mahmoud \& Enanny, Faiza. 2009. Leadership: An Islamic Perspective. Canada: Memorial University of Newfoundland.

[12] Hamzah, Masnur. 2010. Quranic Leadership: Seni Memimpin Gaya Al-Quran (Quranic Leadership: The Art of Leading with the Quran). Batu Caves: PTS Islamika Sdn. Bhd.

[13] Hussin, Hasnah. 2009. Artikel Kenegaraan dan Hubungan Etnik (Article of Nationhood and Ethnic Relations). Kuantan: Penerbit Universiti Malaysia Pahang.

[14] Ibrahim, Ismail. 2013. 1Malaysia dari perspektif agama: Islam dalam perlembagaan dan amalan umat Islam Malaysia (1Malaysia from a Religious Perspective: Islam in the constitution and the practices of Malaysian Muslims) in Mohd Sohaimi Esa, Ismail Ali, Dayu Sensalu \& Lai Yew Meng (eds. ). Gagasan 1Malaysia: Isu dan Cabaran (1Malaysia Concept: Issues and Challenges). Kota Kinabalu: Universiti Malaysia Sabah.

[15] Ismail, Harlina. 2008. Wawasan 2020 (Vision 2020) in Yusof Ismail (ed. ). Dasar- dasar Utama Kerajaan Malaysia (Major Policies of the Malaysian Government) Kuala Lumpur: A. S. Nordeen.

[16] Jaafar, Faridah. 2007. Perdana Menteri dan Dasar Luar Malaysia 1957-2005 (Prime Ministers and Malaysia's Foreign Policies 1957-2005). Kuala Lumpur: Penerbit Universiti Malaya.

[17] Karimi, Barine A. 2007. Successful Leadership: 8 Principles You Must Know. U. S. A: ABC Book Publishing.

[18] Md. Zin, Abdullah \& Jusoh, Khairil Annas. 2012. Pendekatan Wasatiyyah dalam Menghayati 1Malaysia (A Wasatiyyah Approach in Embracing 1Malaysia). Kuala Lumpur: Kasturi Jingga Sdn. Bhd. 
[19] Muhamat, R. 2010. Kepimpinan dan Pengurusan Islam: Sejarah, Teori dan Pelaksanaan (Islamic Leadership and Management: History, Theory and Execution), Bangi, Universiti Kebangsaan Malaysia.

[20] Northouse, Peter G. 2011. Leadership: Theory and Practice - Fifth Edition. United State: Sage Publication.

[21] Omar, Rusdi \& Mukhtaruddin, Mas Juliana. 2010. Dasar luar Malaysia era Dato' Seri Mohd Najib Tun Razak: Keutamaan dalam aspek hubungan dua hala (Malaysia's foreign policies in Dato' Seri Mohd Najib Tun Razak's era: The priorities in a two-way relationship) in Proceeding Seminar on National Resilience (SNAR 2010) Political Managements and Policies in Malaysia. July 13-15, 2010, Hotel Bayview, Langkawi. Organized by Institute of Tun Dr. Mahathir Mohamad's Thoughts, Universiti Utara Malaysia, Sintok, Malaysia.

[22] Pandian, Sivamurugan. 2007. Abdullah Ahmad Badawi: 3 Tahun di Putrajaya (Abdullah Ahmad Badawi: 3 Years in Putrajaya). Kuala Lumpur: Utusan Publication \& Distributors Sdn. Bhd.

[23] Wariya, Chamil. 2004. Abdullah Ahmad Badawi: Perjalanan Politik PM ke-5 (Abdullah Ahmad Badawi: The Political Journey of the Fifth Prime Minister). Kuala Lumpur: Utusan Publications \& Distributors Sdn. Bhd.

[24] Zakaria, Zabri. 2010. Peralihan Dasar Perdana Menteri (Transition of the Prime Minister's Policies). Kajang: Time Edition. 